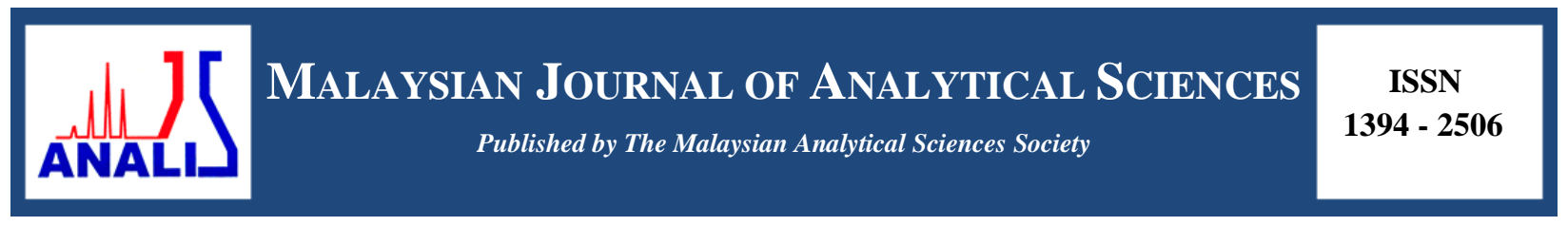

\title{
NITROGEN USE EFFICIENCY IN MR219-4 AND MR219-9 RICE MUTANT LINES UNDER DIFFERENT WATER POTENTIALS AND NITROGEN LEVELS USING ${ }^{15} \mathrm{~N}$ ISOTOPIC TRACER TECHNIQUE
}

\author{
(Kecekapan Penggunaan Nitrogen dalam Padi Titisan Mutan MR219-4 dan MR219-9 di bawah \\ Potensi Air dan Aras Nitrogen yang Berbeza Menggunakan Teknik Isotop Penyurih ${ }^{15} \mathrm{~N}$ ) \\ Ahmad Nazrul Abd Wahid ${ }^{1,2}$, Sahibin Abdul Rahim ${ }^{1}$, Khairuddin Abdul Rahim², Abdul Rahim Harun ${ }^{2}$ \\ ${ }^{1}$ Environmental Science Programme, \\ School of Environmental and Natural Resource Science, Faculty of Science and Technology, \\ Universiti Kebangsaan Malaysia, 43600 UKM Bangi, Selangor, Malaysia \\ ${ }^{2}$ Agrotechnology and Bioscience Division, \\ Malaysian Nuclear Agency, 43000 Kajang, Bangi, Selangor, Malaysia \\ *Corresponding author: a_nazrul@nuclearmalaysia.gov.my
}

Received: 3 August 2015; Accepted: 29 March 2016

\begin{abstract}
This study was conducted to evaluate the nitrogen use efficiency of rice mutant lines of MR219, viz. MR219-4 and MR219-9, developed under rice radiation mutagenesis programme for adaptability to aerobic conditions, grown under conditions of varying water potentials and nitrogen levels in a shade house. Direct ${ }^{15} \mathrm{~N}$ isotopic tracer method was used in this study, whereby the ${ }^{15} \mathrm{~N}$ labeled urea fertilizer was utilized as a tracer for nitrogen nutrient uptake by the test crops. ${ }^{15} \mathrm{~N}$ isotope presence in the samples was determined by using emission spectrometer analysis and percentage of total nitrogen was determined by using Kjeldahl method. ${ }^{15} \mathrm{~N}$ atom access values of the samples were to determine the efficiency of $\mathrm{N}$ use by the mutant varieties. In this work, the data of yield components, viz. grain yield, plant biomass, plant height and 1000 grain weight, and nitrogen components viz, total N, \% nitrogen derived from labeled fertilizer (\% Ndff), \% nitrogen derived from soil (\% Ndfs), nitrogen uptake, fertilizer nitrogen use and nitrogen use efficiency were obtained. Results from this study showed a significant difference to the nitrogen component and yield when there is a change in the rate of fertilizer and water potential. However, varietal factor does not show any significant differences.
\end{abstract}

Keywords: mutant lines of rice, aerobic condition, water potentials, ${ }^{15} \mathrm{~N}$ isotopic tracer, nitrogen use efficiency

\begin{abstract}
Abstrak
Kajian ini telah dijalankan untuk menilai keberkesanan penggunaan nitrogen padi garisan mutan dari MR219, iaitu MR219-4 dan MR219-9, yang dibangunkan di bawah program mutagenesis untuk penyesuaian ke keadaan aerob dan ditanam dalam keadaan potensi air dan aras nitrogen yang berbeza di dalam rumah teduhan. Kaedah isotop penyurih ${ }^{15} \mathrm{~N}$ secara terus telah digunakan dalam kajian ini, di mana baja urea berlabel isotop ${ }^{15} \mathrm{~N}$ digunakan sebagai penyurih untuk pengambilan nutrien nitrogen oleh tanaman ujian. Kehadiran isotop ${ }^{15} \mathrm{~N}$ dalam sampel ditentukan dengan analisis spektrometer pelepasan dan peratusan jumlah nitrogen di dalam sampel ditentukan dengan menggunakan kaedah Kjeldahl. Nilai akses Atom ${ }^{15} \mathrm{~N}$ yang terkandung dalam sampel akan digunakan dalam penentuan keberkesanan penggunaan nitrogen dalam baja melalui formula pengiraan tertentu. Melalui kajian ini, data daripada komponen hasil (hasil bijirin, berat biojisim, ketinggian tumbuhan dan 1000 berat bijirin) dan komponen nitrogen (jumlah nitrogen, \% Ndff, \% Ndfs, pengambilan nitrogen, penggunaan baja nitrogen dan kecekapan penggunaan nitrogen) telah diperolehi. Hasil daripada kajian ini telah menunjukkan terdapat perbezaan yang ketara terhadap komponen nitrogen dan hasil tanaman apabila terdapat perubahan faktor kadar baja dan potensi air. Walaubagaimanapun, faktor varieti tidak menunjukkan apa - apa perbezaan yang ketara.
\end{abstract}




\section{Ahmad Nazrul et al: NITROGEN USE EFFICIENCY IN MR219-4 AND MR219-9 RICE MUTANT LINES UNDER DIFFERENT WATER POTENTIALS AND NITROGEN LEVELS USING ${ }^{15} \mathrm{~N}$ ISOTOPIC TRACER TECHNIQUE}

Kata kunci: titisan mutan padi, keadaan aerob, potensi air, isotop penyurih ${ }^{15} \mathrm{~N}$, kecekapan penggunaan nitrogen

\section{Introduction}

Malaysia's rice production is presently focused in the major irrigated rice areas in Peninsular Malaysia, contributing to $85 \%$ of the national rice production. The main method of rice cultivation in Malaysia is through flooding. This type of cultivation consumes a very high amount of water, where about 3000 litre of water are used to produce $1 \mathrm{~kg}$ of rice [1]. Over $80 \%$ of the freshwater resources in Asia are used for irrigation and about half the amount is consumed for rice [2]. In Malaysia, rice is grown in two seasons where the first season is between August to February, meanwhile the second season is between March to July. Water demands during the first season are less worrying because the rainy season is likely to occur, however during the second season, low rainfall and drought are likely to occur thus the high demand of water is crucial. Rice field will experience drought due to a short supply of water by declining rainfall and dam water level. Globally climate change due to global warming is said to contribute to the water shortage in rice production. Increase in freshwater scarcity has threatened the sustainability of irrigated rice ecosystems [3].

For strategic water management and utilization purposes, the traditional submerged rice cultivation system is gradually moving toward a system where rice is grown in low water input and aerobic conditions while maintaining high productivity. Aerobic cultivation is a planting system where rice is grown in well-drained, non-puddle, and non-saturated soils. In aerobic rice systems, fields remain unsaturated throughout the season. Crop yields are on average only 1000 to $2000 \mathrm{~kg} / \mathrm{ha}$ ) because of adverse environmental conditions (poor soils, little rainfall, weeds), low use of external inputs, and low yield potential of upland rice cultivars [4]. Evidence from studies showed that aerobic rice used only $50 \%$ of the water compared with the lowland rice [5]. The aerobic cultivation can reduce the total water usage by $27-51 \%$ and increase water productivity by $32-88 \%$ [6]. Most countries that suffer from water shortages have been using aerobic cultivation method in their rice farming system. Therefore, steps have been taken including the production of various types of new cultivars is suitable for planting in their aerobic condition. Through a radiation-induced mutation breeding project (IRPA 01-01-03-000/PR0068/0504) using the high yielding and good quality rice MR 219, Malaysian Nuclear Agency (Nuclear Malaysia), in collaboration with Malaysian Agricultural Research and Development Institute (MARDI) and Universiti Putra Malaysia (UPM), discovered an advanced mutant line MR 219-4 and MR 219-9 varieties.

Nitrogen is one of the essential macronutrients for rice growth and becomes the main factors to be considered for developing high-yielding rice cultivar [7]. Nitrogen $(\mathrm{N})$ requirements of the rice plant are supplied from soil and fertilizer. Due to the acute shortage of nitrogen in the soil mostly, nitrogenous fertilizer must be used to meet the needs of the plant. In flooded rice ecosystems, some reports said that nitrogen fertilizer used for rice crops have been lost partly through different mechanisms including ammonia volatilization, denitrification, leaching and run by water [8, 9]. Nitrogen losses can cause environmental problems such as pollution of the atmosphere, aquatic systems and ground water in a bowl. Nitrogen use efficiency is generally low with normally less than $30-40 \%$ of the applied $\mathrm{N}$ took up by flooded rice [10 - 12]. This situation challenges the researchers to develop the strategies to increase nitrogen use efficiency in rice production. Increasing of nitrogen use efficiency offers the greatest economic benefits to farmers and countries. Nitrogen use efficiency may be defined as yield per unit input. In agriculture, this is usually related to the input of nitrogen fertilizer, whereas in scientific literature the nitrogen use efficiency is often expressed as fresh weight or product yield per content of nitrogen. Thus, nitrogen use efficiency can be defined as nitrogen absorbed by a plant to growth and gave yield [13]. Nitrogen use efficiency of crops can be improved by adopting adequate management practices. The usage of $\mathrm{N}$ fertilizers with an adequate amount, form, and methods of application are important management strategies of this element [14].

Although Malaysia has produced aerobic rice varieties and rice adaptable to low water inputs, including MR219-4 and MR219-9, information on nitrogen use efficiency (NUE) of these new lines is negligible. In Malaysia, aerobic rice cultivation is a recent development and there are only a handful of agencies who conducted tests on this rice. In addition to using minimal water, aerobic rice research purposes in Malaysia also aims to improve the effectiveness use of nitrogen in the aerobic rice ecosystem. The previous report stated that changes in water management of flood 
conditions to aerobic conditions affecting the availability and forms of nitrogen present in the soil [15]. Change in water management can have a significant impact on the availability of nutrient intake by plants and lost in the environment [16]. There are few reports that have indicated the use of nitrogen fertilizer on dry land is more efficient [17] and nitrogen application improved rice plant growth under continuous aerobic rice cropping, but for phosphorus $(\mathrm{P})$ and potassium $(\mathrm{K})$ and other micronutrients had a little or no effect [18]. Improvement of nitrogen use efficiency is an essential pre-requisite for expansion of crop production into marginal lands with low nutrient availability. Nitrogen use efficiency depends on the ability to efficiently take up the nutrient from the soil, but also on transport, storage, mobilization, usage within the plant, and even on the environment.

The only direct means of measuring nitrogen use efficiency from the applied fertilizer is through the use of isotopes. In nitrogen efficiency study, a labelled fertilizer ${ }^{15} \mathrm{~N}$ is added to the soil and the amount of nitrogen that a plant has taken up is determined. In this way, different nitrogen fertilizer practices (placement, timing, sources, etc.) were studied [19]. Isotopic studies using ${ }^{15} \mathrm{~N}$ labelled plant materials have been useful in estimating crop $\mathrm{N}$ uptake [20 22].

The objective of this study is to examine the effects of nitrogen levels and water potentials on yield components and to evaluate the nitrogen use efficiency on MR 219-4 and MR 219-9 mutant lines under different water potential and different nitrogen availability. This data can be used as a reference to farmers or any party who wish to develop and implement aerobic rice industry in this country. Through this study, the added value will be assigned to MR 219-4 and MR 219-9 rice mutant lines.

\section{Study location}

\section{Materials and Methods}

Aerobic rice cultivation exercise was carried out in a paddy shield house in Malaysian Nuclear Agency. The shade house provided some control on environmental factors, including rain shelter facilities.

\section{Rice varieties}

Two types of mutant lines rice varieties namely MR219-4 and MR219-9 were used in this experiment. Both varieties are produced by mutation induction using gamma irradiation on MR219 variety (parent). Mutation induction was carried out by exposure of plant organs such as seeds or biological entity to ionizing radiation that can penetrate the tissue cells so that the heritage elements of the chromosome and the process causes the physical changes to the plants [23].

\section{Soil types}

The soil used in this experiment is sandy loam texture with a bulk density of $1.45 \mathrm{~g} / \mathrm{cm}^{3}$. Water retention curve analysis of this soil has been done using pressure plate method. The curve shown in Figure 1 indicated that available water capacity calculated between 10 to $1500 \mathrm{kPa}$ for this soil is about $18 \%$ (w/w).

\section{Experimental design and crop management}

Rice mutants MR219-4 and MR219-9 were planted on loam soil through measuring plot $3 \mathrm{~m}^{2}$ (3m x 1m). Aerobic rice seeds are sown manually at $2 \mathrm{~cm}$ depth and covered with soil. Three watering regimes and three nitrogen levels in a completely randomized block design with three replicates treatment were carried out. Aerobic rice were grown for 110 days under three water potentials, (i) Field capacity from 0 to 40 DAS and saturated from 41 to 110 DAS [ST], (ii) Field capacity from 0 to 110 DAS [FC], and (iii) Field capacity from 0 to 40 DAS and $70 \%$ of field capacity from 41 to 110 DAS [SS]. DAS is standing for days after sowing. Nitrogen in the form of ${ }^{15} \mathrm{~N}$-labeled urea $\left(5.20 \%\right.$ atom excess) was applied in three rates; none $\left(0 \mathrm{~kg} \mathrm{~N} \mathrm{ha}^{-1}\right)$, moderate $\left(60 \mathrm{~kg} \mathrm{~N}^{-1}\right)$ and high $\left(120 \mathrm{~kg} \mathrm{~N} \mathrm{ha}^{-}\right.$ ${ }^{1}$ ) in three splits at 7 days after emergence, 35 days after emergence and 60 days after emergence, respectively. Basal fertilizers of phosphorus from triple superphosphate (TSP) at $60 \mathrm{~kg} \mathrm{P}_{2} \mathrm{O}_{5} \mathrm{ha}^{-1}$ and potassium from muriate of potash (MOP) at $60 \mathrm{~kg} \mathrm{~K}_{2} \mathrm{O} \mathrm{ha}{ }^{-1}$ were applied at 15 days and 65 days after emergence. A tensiometer, an instrument that directly measured soil moisture continuously was installed. Soil moisture was measured and observed daily. 


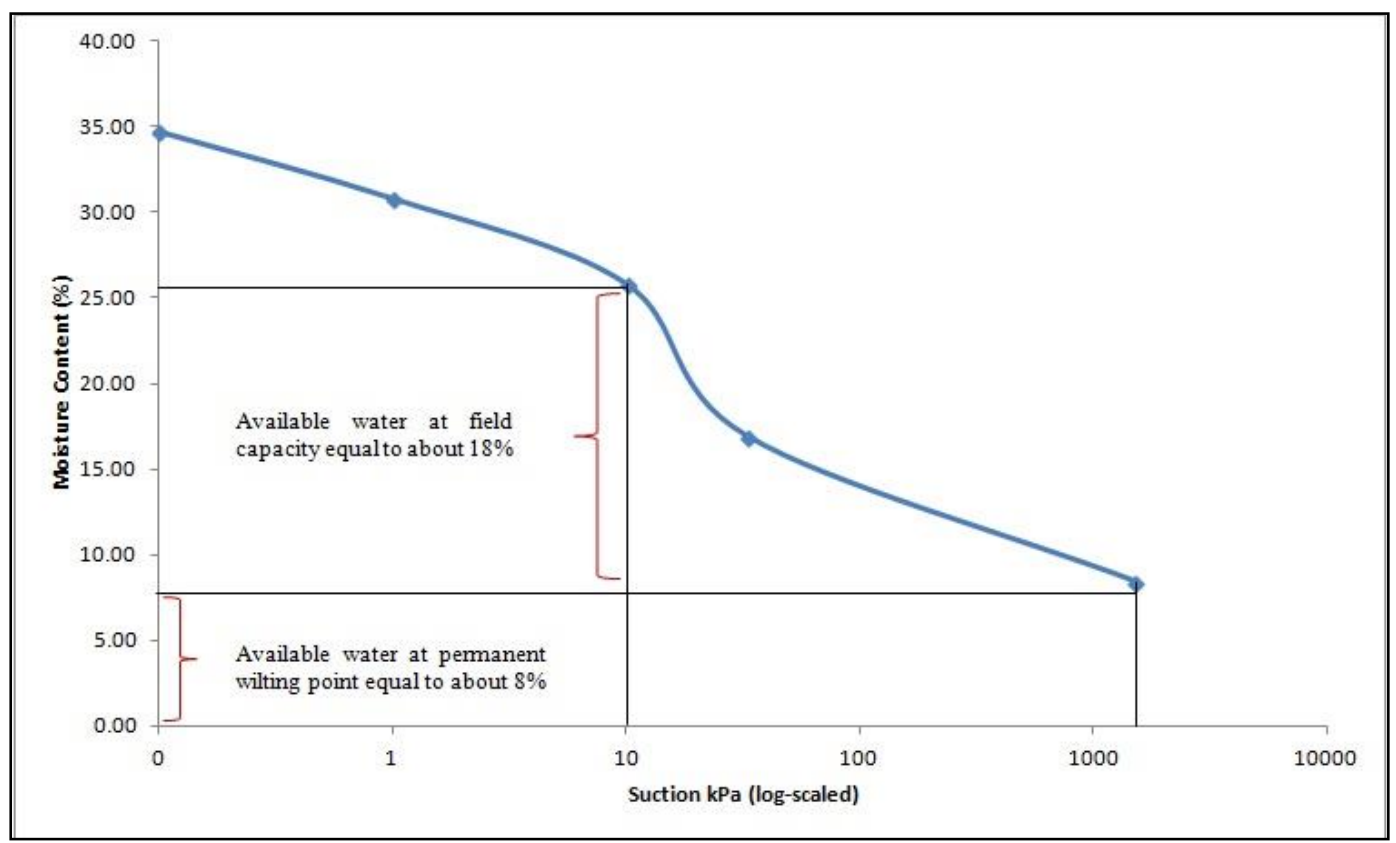

Figure 1. Soil water retention curve for soil moisture content

\section{Plant sampling and analysis}

Paddy plants were sampled after 110 days when the aerobic rice has matured and ripened. Harvesting and sampling were done on a $1 \mathrm{~m} \times 0.5 \mathrm{~m}$ area $\left(0.5 \mathrm{~m}^{2}\right)$. Total plant biomass was weighed to obtain the overall fresh weight. Plant parts such as straw, leaf and grain were separated and measured the fresh weight. Straw, leaf, and grain samples were oven dried at 70 to $80{ }^{\circ} \mathrm{C}$ for three days after which they were weighed and finely milled for further analysis.

Total nitrogen content in straw, leaf and grain was extracted by Kjeldahl digestion followed by steam distillation and subsequently ${ }^{15} \mathrm{~N}$ content was analyzed using emission spectrometer [24]. Percentage of ${ }^{15} \mathrm{~N}$ abundance was transformed into atom percentage ${ }^{15} \mathrm{~N}$ excess by subtracting the natural abundance $(0.3663$ atom $\% \mathrm{~N})$ from the percentage of $\mathrm{N}$ abundance of the sample.

\section{Kjeldahl digestion method}

The Kjeldahl digestion is a method for determination of nitrogen content in rice samples. The Kjeldahl method consist of three main steps; (i) Digestion, where the decomposition of nitrogen in plants samples utilizing a concentrated acid solution. This part was accomplished by boiling a homogeneous sample in concentrated sulphuric acid. The end result is an ammonium sulphate solution. (ii) Distillation, where adding an excess base to the acid digestion mixture to convert $\mathrm{NH}_{4}{ }^{+}$to $\mathrm{NH}_{3}$, followed by boiling and condensation of the $\mathrm{NH}_{3}$ gas in a receiving solution and (iii) Titration to quantify the amount of ammonia in the receiving solution.

\section{Emission spectrometer analysis}

Emission spectrometer is an analytical instrument that be used to determine ${ }^{15} \mathrm{~N}$ isotope tracer in rice samples. Samples were concentrated in liquid forms. An approximately $25 \mu \mathrm{L}$ of samples were put in a glass capsule and placed in an emission spectrometer syringe. Emission spectrometer is equipped with a data acquisition unit which stores the data and automatically converts the measured to the actual value.

\section{Nitrogen components calculation}

After the data were obtained from analysis of samples, the following calculations as expressed in equation $1-6$ were utilised [19]. 


$$
\% N d f f=\frac{\text { atom } \% 15 \mathrm{~N} \text { excess plant }}{\text { atom } \% 15 \mathrm{~N} \text { excess fertilizer }} \times 100
$$

where $N d f f$ is nitrogen derived from fertilizer.

$$
\% N d f s=100-\% N d f f
$$

where $N d f s$ is define as nitrogen derived from soil and $N d f f$ is define as nitrogen derived from fertilizer.

$$
\text { Dry Matter Yield }(\mathrm{kg} / \mathrm{ha})=\mathrm{FW}(\mathrm{kg}) \times \frac{10000\left(\mathrm{~m}^{2} / \mathrm{ha}\right)}{\text { area harvested }\left(\mathrm{m}^{2}\right)} \times \frac{\mathrm{SDW}(\mathrm{kg})}{\mathrm{SFW}(\mathrm{kg})}
$$

where FW is fresh weight per area harvested. Meanwhile SDW and SFW are subsample dry and fresh weight, respectively.

$$
\begin{aligned}
& \text { Nitrogen Yield }(\mathrm{kg} / \mathrm{ha})=\text { Dry Matter Yield }(\mathrm{kg} / \mathrm{ha}) \times \frac{\% \text { Total } \mathrm{N}}{100} \\
& \text { Fertilizer Nitrogen Yield }(\mathrm{kg} / \mathrm{ha})=\text { Nitrogen Yield }(\mathrm{kg} / \mathrm{ha}) \times \frac{\% \text { Ndff }}{100} \\
& \% \mathrm{NUE}=\frac{\text { Fertilizer Nitrogen yield }}{\text { Rate of Nitrogen application }} \times 100
\end{aligned}
$$

where NUE is nitrogen use efficiency. Nitrogen use efficiency is a quantitative measure of the actual uptake of fertilizer nutrient by the plant in relation to the amount of nutrient added to the soil as fertilizer. A common form of expression of fertilizer use efficiency is plant recovery of the added fertilizer.

\section{Statistical analysis}

Analysis of variance (ANOVA) for variables that was used for testing treatment differences (water and nitrogen treatments and independent T-Test to compare mean between two varieties) was carried out. Correlation analysis was used to evaluate the relationship between nitrogen rates and grain yield. General linear model was used to test the interaction between treatments.

\section{Total Nitrogen}

\section{Results and Discussion}

Total Nitrogen (Total $\mathrm{N}$ ) is the sum of nitrate $\left(\mathrm{NO}^{3}\right)$, nitrite $\left(\mathrm{NO}^{2}\right)$, organic nitrogen and ammonia (all expressed as $\mathrm{N})$. It can be measured in the laboratory using Kjeldahl method. Figure 2 shows the differences in total $\mathrm{N}$ contained in plant parts of aerobic rice variety under different nitrogen fertilizer application levels and water potentials. It shows there is no significant different in MR219-4 and MR219-9 rice lines in terms of total $\mathrm{N}$ on three plant parts (straw, leaf and grain) with different nitrogen levels and water potentials $(p>0.05)$. It means total $\mathrm{N}$ in all parts of aerobic rice are not affected by a varietal factor. However, an analysis of ANOVA test shows nitrogen application levels give a clear significant difference or effect on the total $\mathrm{N}$ content in plant parts $(\mathrm{p}<0.05)$ but water potentials remain do not have a significant effect on total $\mathrm{N}$ in paddy plants. Referring to Figure 2, it also shows that most cases a total $\mathrm{N}$ in the straw is higher than leaf and grain. Pirmoradian et al. [25] reported similar finding in this study were increasing of nitrogen levels has significantly affected the total $\mathrm{N}$ content in the rice straw and leaf.

\section{Yield components}

The experimental results for analysis of variance for yield components such as grain yield, biomass, plant height and weight of 1000 grains are summarized in Table 1. Water potentials and nitrogen levels gave significance effects to the yield components except for 1000 grain weight, where there was apparently no effect by nitrogen treatments. The varietal factor does not show any significant effect of the yield components. It means, there are no 
significant different between MR219-4 and MR219-9 in terms of yield components. The significant interactions occurred for total biomass weight and 1000 grain weight with the main treatments factors such as water and nitrogen was included. However, the other interaction effects do not have a significant different to all yield components. From this table, we can conclude that water and nitrogen factors have very importance roles to the yield components in aerobic rice ecosystem.

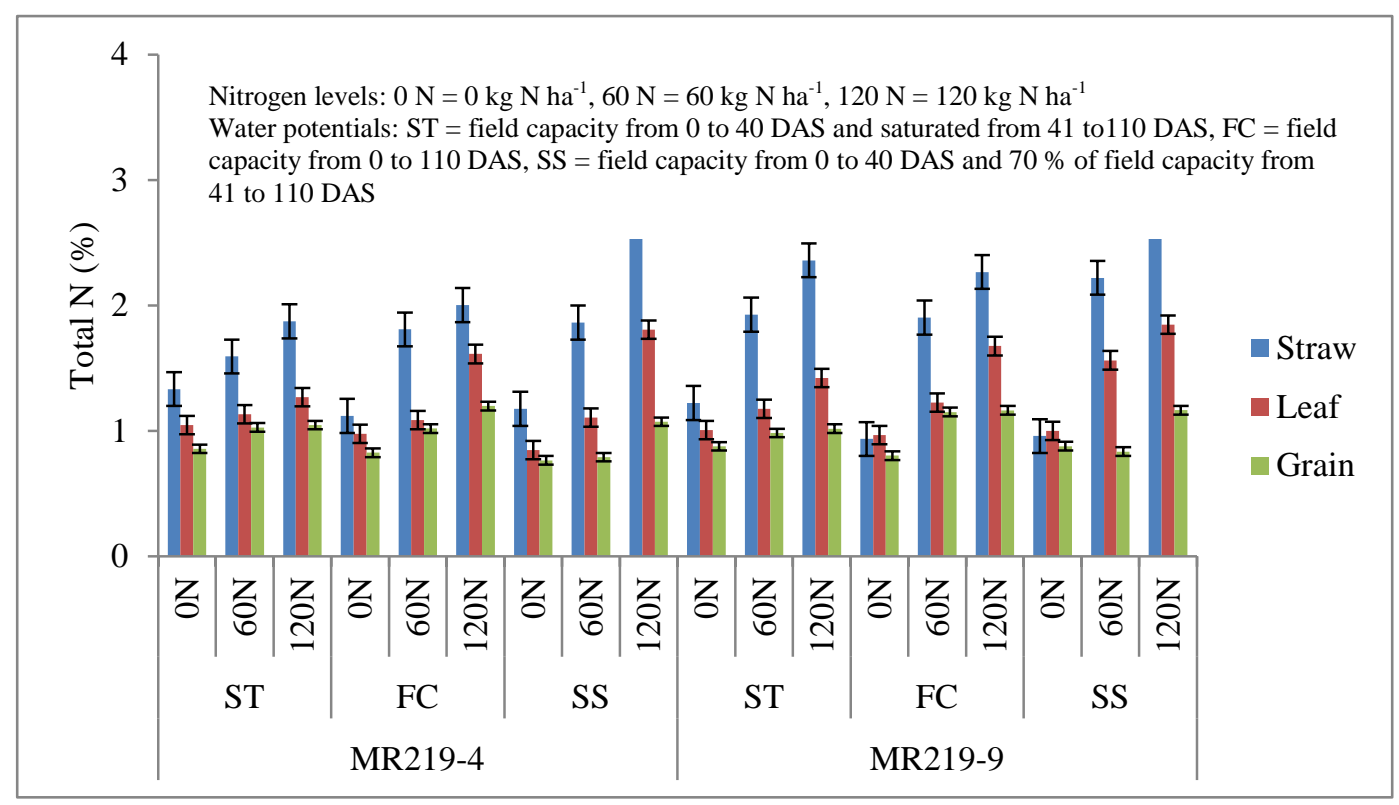

Figure 2. The differences in total $\mathrm{N}$ in plant parts of MR219-4 and MR219-9 mutant lines under different nitrogen levels and water potentials. Error bars denote standard errors.

Table 1. Analysis of variance effect of the treatments on the yield components

\begin{tabular}{ccccc}
\hline \multirow{2}{*}{$\begin{array}{c}\text { Source of } \\
\text { Variations }\end{array}$} & \multicolumn{4}{c}{ Levels of Significance $^{\mathbf{b}}$} \\
\cline { 2 - 5 } & $\begin{array}{c}\text { Grain } \\
\text { Yield } \\
\left(\mathbf{k g ~ h a}^{-1}\right)\end{array}$ & $\begin{array}{c}\text { Total Biomass } \\
\text { Weight } \\
\left(\mathbf{k g ~ h a}^{-1}\right)\end{array}$ & $\begin{array}{c}\text { Plant } \\
\text { Height } \\
(\mathbf{c m})\end{array}$ & $\begin{array}{c}\text { 1000-grain } \\
\text { Weight } \\
(\mathbf{g})\end{array}$ \\
\hline W & $* *$ & $* *$ & $* *$ & $* *$ \\
N & $* *$ & $* *$ & $* *$ & NS \\
V & NS & NS & NS & NS \\
W x N & NS & $* *$ & NS & $* *$ \\
W x V & NS & NS & NS & NS \\
N x V & NS & NS & NS & NS \\
W x N x V & NS & NS & NS & NS \\
\hline
\end{tabular}

${ }^{\mathrm{a}} \mathrm{W}=$ Water potential, $\mathrm{N}=$ Nitrogen rates and $\mathrm{V}=$ Variety, ${ }^{\mathrm{b}}$ Levels of significance indicated: NS $=$ Not significant, $* *=$ Significance at $p \leq 0.05$ 
The importance of nitrogen to the aerobic rice yield under different water potentials was illustrated in Figure 3 and 4 respectively. Finding study showed that nitrogen level factors have a very strong and significance relationship with the grain yield of both varieties despite the differences in soil water potentials.

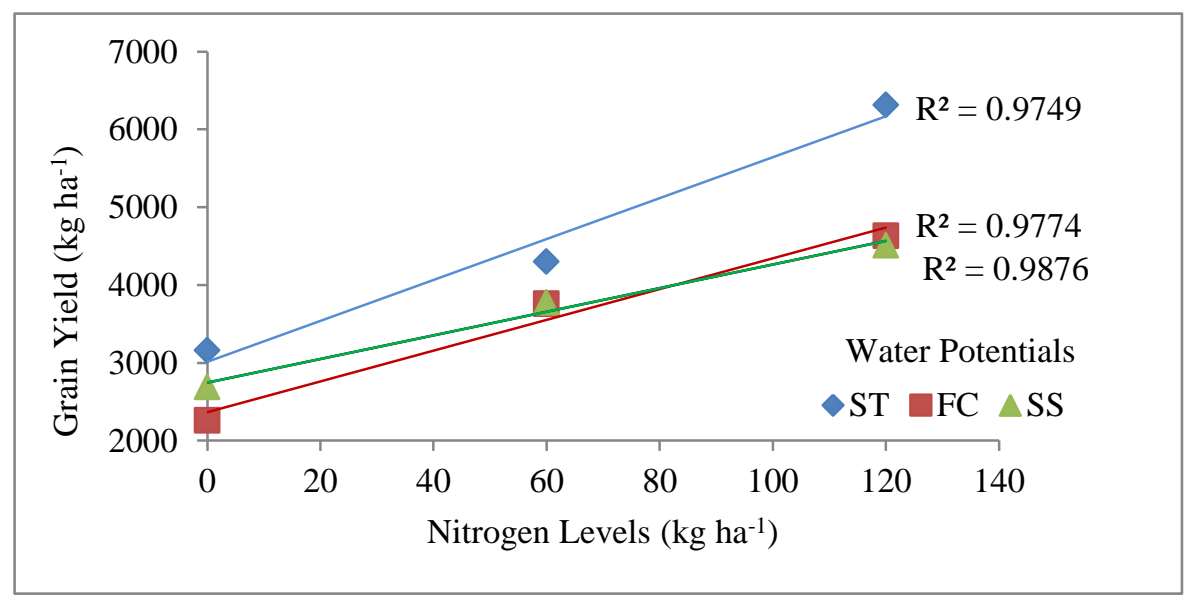

Figure 3. The relationship between nitrogen fertilizer levels on MR219-4 mutant line under different water potentials

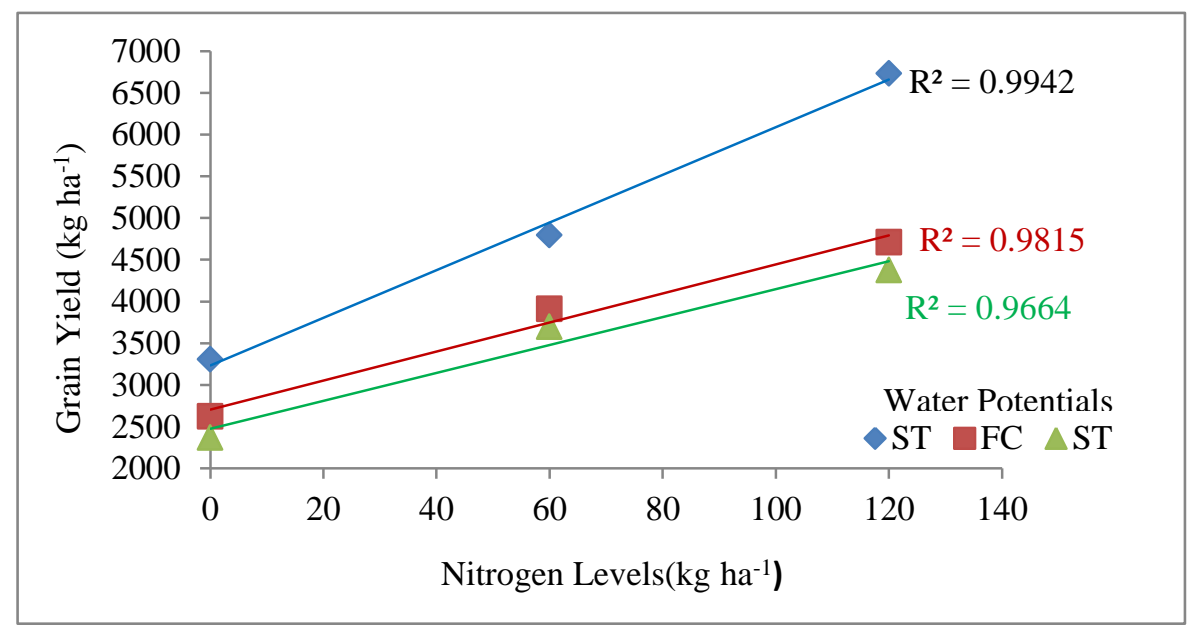

Figure 4. The relationship between nitrogen fertilizer levels on MR219-9 mutant line under different water potentials

\section{Nitrogen components}

The experimental results for analysis of variance for nitrogen components such as nitrogen derived from fertilizer $(N d f f)$, nitrogen derived from soil ( $N d f s$ ), nitrogen uptake (NU), fertilizer nitrogen yield (FNY), and nitrogen use efficiency (NUE) were summarized in Table 2 . The result clearly showed that only nitrogen level treatments give the significant effect to the percentage of $N d f f$ and $N d f s$ but not on the water potential treatments. However, both nitrogen level and water potential treatments are displayed a significant effect to the NU, FNY and NUE. Nayak et al. [26] also found a similar result related to nitrogen levels effect on NU and FNY where increasing the rates of 


\section{Ahmad Nazrul et al: NITROGEN USE EFFICIENCY IN MR219-4 AND MR219-9 RICE MUTANT LINES UNDER DIFFERENT WATER POTENTIALS AND NITROGEN LEVELS USING ${ }^{15} \mathrm{~N}$ ISOTOPIC TRACER TECHNIQUE}

nitrogen fertilizer application cause a significant effect to NU and FNY. Mannan et al. [27] found NU and FNY on rice crop is lower under water stressed compared to none stressed condition, similar to this study where NU and FNY on both rice varieties is lower under inadequate water supply condition. This study also showed that there are significant interactions between water and nitrogen that influence only the NU and NUE but not FNY. However, the other interaction effects do not have a significant different at all nitrogen components. Both varieties MR219-4 and MR219-9 also found not have significant different with each other at all nitrogen components.

Table 2. Analysis of variance effect of the treatments on the nitrogen components

\begin{tabular}{cccccc}
\hline \multirow{2}{*}{ Source of Variations $^{\text {a }}{ }^{*}$} & \multicolumn{5}{c}{ Levels of Significance $^{\mathbf{b}}$} \\
\cline { 2 - 6 } & \% Ndff & \% Ndfs & NU & FNY & NUE \\
\hline W & NS & NS & $* *$ & $* *$ & $* *$ \\
N & $* *$ & $* *$ & $* *$ & $* *$ & $* *$ \\
V & NS & NS & NS & NS & NS \\
W x N & NS & NS & $* *$ & NS & $* *$ \\
W x V & NS & NS & NS & NS & NS \\
N x V & NS & NS & NS & NS & NS \\
W x N x V & NS & NS & NS & NS & NS \\
\hline
\end{tabular}

${ }^{\mathrm{a}} \mathrm{W}=$ Water potential, $\mathrm{N}=$ Nitrogen rates and $\mathrm{V}=$ Variety, ${ }^{\mathrm{b}}$ Levels of significance indicated: NS $=$ Not significant, $* *=$ Significance at $p \leq 0.05$

\section{Nitrogen use efficiency (NUE)}

Nitrogen use efficiency (NUE) for MR219-4 and MR219-9 rice mutant lines, shown in Figure 5 depict the influence of nitrogen application rates on both rice varieties under different water potentials. The result clearly indicated a significant difference of NUE between different water potentials and nitrogen levels. Water treatment at field capacity from 0 to 110 days $[\mathrm{FC}]$ showed higher NUE than other water potentials for both varieties. This study also showed that at FC water regime with nitrogen level $60 \mathrm{~kg} \mathrm{~N} \mathrm{ha}^{-1}, \mathrm{~N}$ was utilized more than $50 \%$ to produce yield. These results indicated that the use of absorbed nitrogen from soil at the level of $60 \mathrm{~kg} \mathrm{~N} \mathrm{ha}^{-1}$ at FC level is more efficient than others. It also proved that changes in water level in the soil can influence the intake of nitrogen by plants. At field capacity 0 to 40 days and saturated from 40 to 110 days [ST] water potential the NUE is slightly lower than FC. Stagnant water conditions at ST level may have caused some nitrogen fertilizer loss through leaching and water runoff.

In this study, nitrogen dynamics data on varieties MR219-4 and MR219-9 rice mutant lines was obtained. Initial data for this crop is very important as aerobic rice cultivation for these varieties is still in the initial stage in Malaysia. However, this study was only made in the shade house where environmental factors were controlled. In future work, studies on the nitrogen dynamics for this crop using isotope techniques can be extended up to the farm level.

The nitrogen use efficiency is affected by several factors, but in most cases for a given irrigation management and water regime, the nitrogen fertilizer rate is the main source of variation, especially with regard to the nitrogen uptake issue. Avoiding over fertilization is the utmost means to match a high use efficiency and economic return of nitrogen fertilizer with limited environmental risks from nitrogen losses. This study has shown that use of high nitrogen rates does not mean that the efficiency of nitrogen use by plants is also high. Farmers in Malaysia should wisely control the use of nitrogen fertilizer on their crops. Excessive use of fertilizers will certainly increase the cost of farming besides doesn't necessarily increase rice production. Apart from the increase in expenditure high nitrogen application is also detrimental to the environmental health issue. 


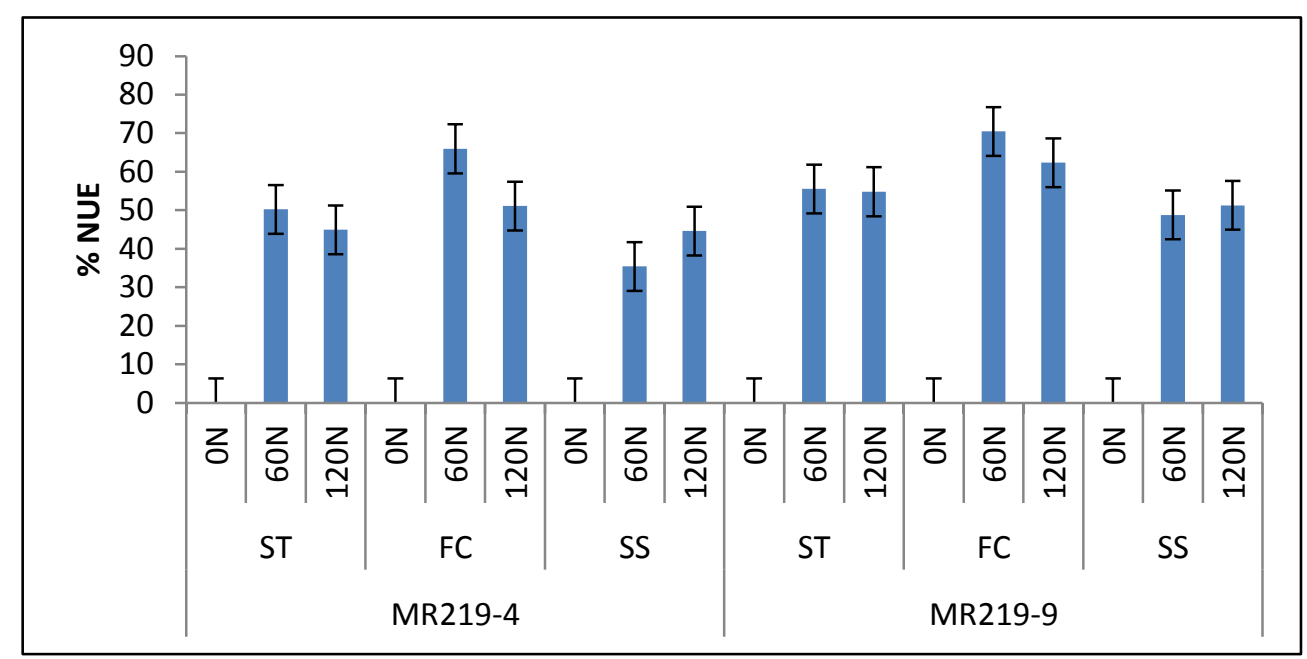

Figure 5. The influence of nitrogen level on nitrogen use efficiency (NUE) on MR219-4 and MR219-9 mutant lines under different water potentials. Error bars denote standard errors.

\section{Conclusion}

The present study highlighted the nitrogen use efficiency at a different range of nitrogen levels under different water potentials. In this work, we can conclude that nitrogen and water are affecting yield and nitrogen components on aerobic rice MR219-9 and MR219-4 ecosystem. It clearly shows that nitrogen and water level of application are very important inputs in the aerobic rice industry. Increasing nitrogen rates application may increase the yield but in some water condition, nitrogen use efficiency is low despite high fertilizer rates. Nitrogen use efficiency is optimum at field capacity for $60 \mathrm{Kg} \mathrm{N} \mathrm{ha}^{-1}$ treatment. Change in soil water potential from flood to aerobic condition is proven to give a good improvement in the efficiency of nitrogen fertilizer uptake. Both aerobic rice MR219-4 and MR219-9 mutant lines exhibit no significant differences in terms of yield and nitrogen components.

\section{Acknowledgement}

The first author would like to acknowledge the Government of Malaysia for the scholarship granted to pursue his M.Sc. study at the Faculty of Science and Technology, The National University of Malaysia, Bangi. The present research is funded by MOSTI ScienceFund Grant: 06-03-01-SF0203. The work presented in this paper has been carried out at the Malaysian Nuclear Agency, Bangi, Kajang, Selangor. The capable technical assistance by Latiffah Norddin, Abdul Razak Ruslan and Hazlina Abdullah is deeply appreciated.

\section{References}

1. Sariam, O., Khanif, Y. M. and Zahrah, T. (2002). Rice growth and nitrogen uptake as influenced by water management. Malaysian Journal of Soil Science, 6: 1 - 11.

2. Dawe, D., Seckler, D. and Barker, R. (1998). Water supply and research for food security in Asia. Proceeding of the workshop on increasing water productivity and efficiency in rice-based system, IRRI, Los Banos Philippines.

3. Tuong, T. P. and Bouman, B. A. M. (2003). Rice production in water-scarce environments. In water productivity in agriculture: Limits and opportunities for improvement. Eds. J W Kijne, R Barker, D Molden: 53 $-67$.

4. Priyanka, S., Jitesh, B. and Babu, S. (2012). Aerobic rice, a new approach of rice cultivation. International Journal of Research in BioSciences, 1(1): $1-6$.

5. Sheng, C. C., Kimi, S., Man, A. and Hussain, Z. P. (2012). Aerobic rice: producing more rice with less water. http://www.mancid.org.my/index.php?mod=publication\&task=detail\&nid=1 [6 Mac 2014].

6. Bouman, B. A. M. (2005). Rice and water. Advances in Agronomy, 92: 187 - 237. 
7. Duan, Y. H., Zhang, Y. L., Ye, L. T., Fan, X. R., Xu, G. H. and Shen, Q. R. (2007). Responses of rice cultivars with different nitrogen use efficiency to partial nitrate nutrition. Annals of Botany, 99: 1153 - 1160.

8. Choudhury, A. T. M. A. and Kennedy, I. R. (2005). Nitrogen fertilizer losses from rice soils and control of environmental pollution problems. Communications in Soil Science and Plant Analysis, 36: 1625 - 1639.

9. Dobermann, A. and Fairhurst, T. (2000). Rice: nutrient disorders and nutrient management. Handbook Series, pp. $147-149$.

10. Craswell, E. T. and Vlek, P. L. G. (1979). Fate of nitrogen fertilizer applied to wetland rice. In: Nitrogen and rice, pp. $175-192$.

11. Abou Seeda, M., Soliman, S. and Khater, A. (1994). The assessment of nitrogen balance under flooding and saturation circumstances using N-15. Second Arab Conference on the Peaceful Uses of Atomic Energy, pp. 709 $-721$.

12. De Datta, S. K. (1986). Improving nitrogen fertilizer efficiency in lowland rice in tropical Asia. Fertilizer Research, 9: $171-186$.

13. Janssen, B. H. (1998). Efficient use of nutrients: an art of balancing. Field Crops Research, 56: 197 - 201.

14. Tayefe, M., Gerayzade, A., Amiri, E. \& Zade, A. N. (2011). Effect of nitrogen fertilizer on nitrogen uptake, nitrogen use efficiency of rice. International conference on biology, environment and chemistry, pp. 470 - 473.

15. Savant, N. K. and De Datta, S. K. (1982). Nitrogen transformation in wetland rice soils. Advance in Agronomy, 35: $241-302$.

16. Jing, X., Van, R. H., Shaobing, P., Bouman B. A. M., Romeo, M. V., Lixiao, N., Jianliang, H. and Kehui, C. (2009). Improvement in nitrogen availability, nitrogen uptake and growth of aerobic rice following soil acidification. Soil Science and Plant Nutrition, 55 (5): 705 - 714.

17. Brian, D. (2010). Nitrogen for rice. IREC Farmer's Newsletter - Large Area, 183: 35 - 37.

18. Nie, L., Peng. S. and Bouman B. A. M. (2008). Alleviation of soil sickness cause by aerobic monocropping: growth response of aerobic rice to nutrient supply. Field Crops Research, 107: 129 - 136.

19. IAEA. (2001). Use of isotopes and radiation methods in soil and water management and crop nutrition. Training Course, 14: 21 - 96.

20. Azam, F., Simmons, F. W. and Mulvaney, R. L. (1993). Mineralization of N from plant residues and its interaction with native soil N. Soil Biology and Biochemistry, 25: 1787 - 1792.

21. Jensen, E. S. (1994). Availability of nitrogen in $15 \mathrm{~N}$-labelled mature pea residues to subsequent crops in the field. Soil Biology and Biochemistry, 26: $465-472$.

22. Vanlauwe, B., Swift, M. J. and Merckx, R. (1996). Soil litter dynamics and N use in a leucaena (Leucaena leucocephala Lam. (De Witt) alley cropping system in southwestern Nigeria. Soil Biology and Biochemistry, 28: 739 - 749.

23. Abdul Rahim, H. and Andullah M. Z. (2012). Padi sinaran gama. Dewan Kosmik Majalah Sains dan Teknologi, 20 (10): $10-13$.

24. IAEA. (2001). Use of isotopes and radiation methods in soil and water management and crop nutrition. Training Course, 14: $1-20$.

25. Pirmoradian, N., Sepaskhah, A. and Maftoun, M. (2004). Deficit irrigation and nitrogen effects on nitrogen use efficiency and grain protein of rice. Agronomic EDP Sciences, 24: 143 - 153.

26. Nayak, B. R., Pramnik, K., Panigraphy, N., Dash, A. K. and Swain, S. K. (2015). Yield, nitrogen uptake and nitrogen use efficiency indices of aerobic rice (Oryza sativa L.) under various irrigation regimes and nitrogen levels. International Journal of Bioresources, 1(2): 8 - 13.

27. Mannan, M. A., Bhuiya, M. S. U., Akhand, M. I. M. and Zaman, M. M. (2012). Growth and yield of basmati and traditional aromatic rice as influenced by water stress and nitrogen level. Journal of Science Foundation, 10(2): $52-62$. 